\title{
The association between cognitive decline and short-term blood pressure variability in middle-aged patients with primary hypertension - a pilot study
}

\author{
Jakub Baranowski ${ }^{1 *}$, Karol Klęczar ${ }^{1 *}$, Marta Soltysiak ${ }^{2}$, Krystyna Widecka ${ }^{2}$ \\ 'Students Scientific Association of Department of Internal Diseases and Hypertensiology, Pomeranian Medical University in Szczecin \\ ${ }^{2}$ Department of Internal Diseases and Hypertensiology, Pomeranian Medical University in Szczecin \\ *joint first authors
}

\section{Streszczenie}

Wstęp. Nadciśnienie tętnicze (HTN) jest częstą przyczyną rozwoju zaburzeń czynności poznawczych. Aktualne dane podkreślają rolę HTN w niekorzystnej przebudowie naczyń i promowaniu zmian w obrębie mikrokrążenia mózgowego, prowadzących do upośledzenia funkcji poznawczych. W prezentowanym badaniu szukaliśmy związku między dobową zmiennością ciśnienia tętniczego (BPV) z wykorzystaniem 24-h ambulatoryjnego monitorowania ciśnienia tętniczego (ABPM) a zaburzeniami funkcji poznawczych u pacjentów w średnim wieku obciążonych nadciśnieniem tętniczym.

Materiał i metody. Grupę badaną stanowiło 42 pacjentów z niepowikłanym nadciśnieniem tętniczym (24 kobiety, 18 mężczyzn, średni wiek: 59,1 $\pm 6,1$ r.). BPV oceniono za pomocą ABPM i wyrażono w odchyleniu standardowym (24 MAP SD) i znormalizowanym względnym współczynniku zmienności (CV). Sprawność funkcji poznawczych oceniono z wykorzystaniem Krótkiej Skali Oceny Stanu Psychicznego (MMSE, Mini-Mental State Examination), Testu Rysowania Zegara (CDT, Clock Drawing Test), Montrealskiej Skali Oceny Funkcji Poznawczych (MoCA, Montreal Assessment Cognitive Scale).

Wyniki. W całej grupie badanej wyniki MMSE i CDT mieściły się w zakresie prawidłowym, jedynie w teście MoCA średnie wartości pozostawały poniżej przyjętej normy. Wyniki testów neuropsychologicznych były porównywalne dla grup z prawidłowym i nieprawidłowym (bez spadku nocnego) dobowym profilem BP. Spośród analizowanych parametrów BPV CV ujemnie korelował z wynikami CDT oraz MoCA. Podobnie, 24 MAP wyrażone odchyleniem standardowym korelowało ujemnie z wynikami CDT. W analizie wieloczynnikowej z uwzględnieniem wieku, płci, poziomu wykształcenia oraz zaburzeń lipidowych wyniki testu MoCA były odwrotnie skorelowane z CV. Średnie wyniki w teście MoCA były istotnie niższe u mężczyzn w porównaniu do kobiet.

Wnioski. W badaniu pilotażowym, łagodne upośledzenie funkcji poznawczych u chorych z wieloletnim, niepowikłanym nadciśnieniem tętniczym może być związane ze zwiększoną dobową zmiennością ciśnienia tętniczego.

Słowa kluczowe: upośledzenie funkcji poznawczych, zmienność ciśnienia tętniczego, nadciśnienie tętnicze

Arterial Hypertens. 2018, vol. 22, no. 3, pages: 135-142

DOI: 10.5603/AH.a2017.0013

Address for correspondence: Dr n. med. Marta Soltysiak, Klinika Hipertensjologii i Chorób Wewnętrznych SPSK 1 PUM

ul. Unii Lubelskiej 1, 71-252 Szczecin

tel.: (91) 4253 550faks: (91) 4253552

e-mail: marta.soltysiak00@gmail.com 


\section{Abstract}

Introduction. Hypertension (HTN) is a common cause of cognitive dysfunction. Current data emphasize a role of HTN in the development of unfavourable vascular remodelling and changes in cerebral microcirculation, leading to cognitive decline. In this study, we sought associations between circadian blood pressure variability (BPV) in a $24 \mathrm{~h}$ blood pressure ambulatory monitoring (ABPM) and cognitive decline in middle-aged hypertensive patients. Material and methods. The study group comprised 42 patients with uncomplicated hypertension ( 24 females, 18 males; mean age: $59.1 \pm 6.1$ years). BPV was assessed by ABPM and expressed in standard deviation (24 MAP $\mathrm{SD}$ ) and coefficient of variation (CV). Cognitive performance was evaluated using Mini-Mental State Examination (MMSE), Clock Drawing Test (CDT) and Montreal Assessment Cognitive Scale (MoCA).

Results. In the whole study group, MMSE and CDT scores were within the normal range, but the mean scores were lowered in the MoCA test. All of the neuropsychological test scores were comparable in groups with normal and abnormal (non-dipper) blood pressure patterns. Among the analyzed BPV indicators, CV was negatively correlated with CDT and MoCA scores. 24 MAP expressed in standard deviations was also negatively correlated with CDT scores. In the multivariate analysis, MoCA scores were inversely associated with $\mathrm{CV}$ after adjusting for age, gender, education and abnormal lipid profiles. Mean MoCA scores were significantly lower in men in comparison to women. Conclusions. In this pilot-based study, mild cognitive impairment in middle-aged patients with long-lasting uncomplicated hypertension may be associated with increased diurnal variability of blood pressure.

Key words: cognitive decline, blood pressure variability, hypertension

Arterial Hypertens. 2018, vol. 22, no. 3, pages: 136-142

DOI: 10.5603/AH.a2017.0013

\section{Introduction}

As a consequence of demographic changes related to population ageing, cerebrovascular mortality becomes a significant and increasing healthcare problem. Currently, cerebrovascular disease is the third most frequent cause of death in Poland. In addition, it is also one of the most frequent causes of cognitive dysfunction and vascular dementia (VD) [1-4].

Although the pathogenesis of small vessel disease has not been fully understood, an increasing body of evidence suggests a role of elevated blood pressure in the development of small vessel disease in the network of cerebral arteries [5, 6]. Arterial hypertension (HTN) influence vascular remodelling and progress of atherosclerosis with ageing leading to hypoperfusion of the central nervous system and, as consequence, to the development of ischemic lesions, lacunar strokes and damage of the white matter [7]. Additionally, recent studies have emphasized the potential role of the cerebral renin-angiotensin-aldosterone system (RAAS) in the development of VD and cognitive disorders. RAAS has been found to have an impact on the control of cerebral blood flow, local oxidative processes, and the course of local inflammatory response $[1,8]$.

Currently, a close relationship has been well established between HTN and dementia in the elderly. However, some cross-sectional studies suggest an adverse effect of hypertension on cognitive functions also in the younger age groups [9-11]. Earlier reports demonstrated that accumulated blood pressure load proportionally increase the risk of cerebrovascular complications including VD [12-20], and the enhanced analysis of conventional 24-hour ambulatory blood pressure monitoring (ABPM) data may be useful in predicting cardio- and cerebrovascular outcomes [21-25]. It has been showed that the assessment of short-term systolic blood pressure variability (BPV) and pulse pressure (PP) substantially increase the prognostic value of data derived from conventional ABPM [26]. There have been only a few data in the available literature on the relationship between $\mathrm{BPV}$ and cognitive impairment but they yielded inconclusive results [27-29].

In this pilot study, we aimed to assess the association between BPV and cognitive function in middle-aged patients with uncomplicated primary HTN.

\section{Material and methods}

\section{Study population}

The study group comprised 42 patients ( 24 females, 18 males) aged 45-70 years with spontaneous and uncomplicated hypertension who were referred to the Department of Hypertension \& Internal Diseases in Szczecin from November 2017 to March 
2018 (inclusive). In reference to medical standards, secondary hypertension was excluded based on the routine biochemical and hormonal test and radiological imaging. The study protocol was approved by the Bioethical Committee at the Pomeranian Medical University in Szczecin (KB-0012/53/18). All subjects participating in the study gave their written informed consent.

\section{4-h ABPM protocol}

In all cases, a 24-hour ABPM was performed using Spacelabs 90207 device. Automatic measurements were taken every 20 minutes during the day and every 30 min during the night. Hours from 6.00 to 22.00 were set as a daytime and from 22.00 to 6.00 as a nocturnal period. We analyzed 24-hour, daytime and nocturnal systolic, diastolic and mean blood pressure (24SBP, 24DBP, 24MAP, SBPd, DBPd, MAPd; SBPn, DBPn and MAPn, respectively), and nocturnal fall in systolic blood pressure. According to current guidelines [30], dipping blood pressure profile was defined as a reduction of at least $10 \%$ in overnight blood pressure; non-dipping as a decline less than $10 \%$ : extreme-dipping as a decline above $20 \%$, and reverse dipping if blood pressure was higher at night. As an additional indicator of the short-term circadian blood pressure variations, a 24-hour pulse pressure (PP) and 24-hour mean blood pressure variability expressed in standard deviation (24MAP SD) and coefficient of variation $(\mathrm{CV})$ were calculated.

\section{Assessment of cognitive impairment}

Cognitive impairment was assessed by using the following neuropsychological diagnostic tests: Mini-Mental State Examination (MMSE), Clock Drawing Test (CDT), and Montreal Assessment Cognitive Scale (MoCA). The MMSE is a 30 -item questionnaire that examines functions including registration (repeating named prompts), recall, attention, orientation to time, language use, and the ability to follow simple commands. It is widely used to differentiate various types of dementias. The CDT is a valid complimentary tool to MMSE in the assessment of cognitive impairment severity. The MoCA is a 30-point test assessing multiple cognitive domains and is known as a sensitive tool for detecting mild cognitive impairments. MMSE 27-30, CDT $\geq 6$, MoCA $\geq 26$ scores were assumed as reference values corresponding to the norm.

\section{Statistical analysis}

Descriptive statistics included frequency distribution for categorical variables and means, standard deviation, and range for continuous variables. The
Kolmogorov-Smirnov test, unpaired Student's t-test, Chi-square test, Spearman's rank correlation, and ANCOVA were used to compute differences between groups and to test the associations between study variables. Statistical analyses were performed using STATISTICA Version 12 (StatSoft Inc.).

\section{Results}

Baseline descriptive statistics are given in Table I. The mean age of the study group was $59.1 \pm 6.1$ years (mean $\pm \mathrm{SD}$ ). Mean BMI was $29.5 \mathrm{~kg} / \mathrm{m}^{2}$ but only 8 patients (19\% of all cases) had BMI below $25.0 \mathrm{~kg} / \mathrm{m}^{2}$; the remaining were overweight or obese. Over half of them $(64.3 \%)$ declared their education at least at the secondary level. There was a high prevalence of smokers $(59.5 \%)$, and patients with dyslipidemia (57.1\%) and abnormal glucose tolerance (30.9\%). The total duration of HTN was 12.6 \pm 11.2 years. Positive family history of hypertension was reported by $71.4 \%$ of respondents. Mean results of cognitive tests were within the normal range: $7.9 \pm$ 2.0 scores in CDT and $27.6 \pm 1.8$ scores in MMSE. Only in the MoCA test, mean scores were below the reference range $(24.9 \pm 2.5$ scores $)$.

In the ABPM analysis, mean values of 24-hour systolic, diastolic and MAP pressure were $125.6 \pm$ $13.5,75.9 \pm 9.8$ and $92.9 \pm 9.8 \mathrm{~mm} \mathrm{Hg}$, respectively (Table II). Dipping blood pressure profile was found in $37 \%$, non-dipping in $61 \%$ and reverse-dipping in $2 \%$ of patients. Mean BPV was $12.2 \%$ which corresponded to 11.4 SD.

The results of neuropsychological tests were comparable between groups with normal and abnormal blood pressure profile (Table III). Among the analyzed BPV indicators, CV was inversely correlated with $\operatorname{CDT}(\mathrm{r}=-0.37 ; \mathrm{p}=0.03)$ and MoCA $(\mathrm{r}=$ $-0.36 ; p=0.02$ ), while $S D$ was correlated only with $\operatorname{CDT}(\mathrm{r}=-0.41 ; \mathrm{p}=0.02)$.

In multivariate analysis, after adjustment for including age, sex, education level and coexistence of abnormal lipid profiles (defined as the occurrence of at least one abnormality within LDL-cholesterol, HDL-cholesterol, and triglycerides levels), MoCA score was inversely associated with CV $(\beta=-0.41$; $\mathrm{p}=0.02)$. Overall, males had significantly lower MoCA scores in comparison with females $(\mathrm{p}=0.03)$ (Fig. 1).

\section{Discussion}

The relationship among hypertension and cognitive function is complex, albeit has not been fully 
Table I. Clinical characteristic of the studied group. Data presented as means \pm SD or percent; P-values for unpaired t-tests or chi-square test, respectively

\begin{tabular}{|c|c|c|c|c|c|}
\hline & $\begin{array}{c}\text { All } \\
n=42\end{array}$ & $\begin{array}{c}\text { Females } \\
n=24\end{array}$ & \multicolumn{2}{|c|}{$\begin{array}{c}\text { Males } \\
n=18\end{array}$} & $\begin{array}{c}\text { P-value IF } \\
\text { vs. M }\end{array}$ \\
\hline \multicolumn{6}{|l|}{ Anthropometrics: } \\
\hline Age [years] & $59.1 \pm 6.1$ & $60.1 \pm 6.1$ & \multicolumn{2}{|c|}{$57.8 \pm 6.1$} & 0.24 \\
\hline Body mass index $\left[\mathrm{kg} / \mathrm{m}^{2}\right]$ & $29.8 \pm 5.6$ & $28.7 \pm 4.3$ & 31.2 & 6.9 & 0.16 \\
\hline \multicolumn{6}{|l|}{ Office Blood Pressure: } \\
\hline Systolic blood pressure [mm Hg] & $147.2 \pm 25.0$ & $145.1 \pm 20.3$ & \multicolumn{2}{|c|}{$149.7 \pm 30.1$} & 0.58 \\
\hline Diastolic blood pressure [mm Hg] & $91.4 \pm 12.9$ & $88.1 \pm 10.0$ & \multicolumn{2}{|c|}{$95.3 \pm 15.0$} & 0.08 \\
\hline Mean blood pressure [mm Hg] & $110.0 \pm 15.6$ & $107.1 \pm 11.7$ & \multicolumn{2}{|c|}{$113.4 \pm 19.0$} & 0.21 \\
\hline \multicolumn{6}{|l|}{ Laboratory tests: } \\
\hline Fasting blood glucose $[\mathrm{md} / \mathrm{dL}]$ & $100.1 \pm 18.1$ & $99.4 \pm 13.3$ & \multicolumn{2}{|c|}{$101.1 \pm 23.6$} & 0.76 \\
\hline Above $100 \mathrm{mg} / \mathrm{dl}(\%)$ & $31.0 \%$ & $33.3 \%$ & \multicolumn{2}{|c|}{$27.8 \%$} & 0.70 \\
\hline LDL-cholesterol [mg/dL] & $112.1 \pm 41.2$ & $113.4 \pm 45.8$ & \multicolumn{2}{|c|}{$110.5 \pm 35.8$} & 0.82 \\
\hline Above $100 \mathrm{mg} / \mathrm{dl}(\%)$ & $54.8 \%$ & $54.2 \%$ & \multicolumn{2}{|c|}{$55.6 \%$} & 0.93 \\
\hline HDL-cholesterol [mg/dL] & $54.7 \pm 18.8$ & $60.2 \pm 21.6$ & \multicolumn{2}{|c|}{$47.6 \pm 11.6$} & 0.03 \\
\hline Below 40 (males) or 45 (females) [mg/dl] $(\%)$ & $33.3 \%$ & $37.5 \%$ & \multicolumn{2}{|c|}{$27.8 \%$} & 0.51 \\
\hline Triglycerides [mg/dL] & $132.4 \pm 63.0$ & $144.8 \pm 76.4$ & \multicolumn{2}{|c|}{$116.5 \pm 35.9$} & 0.15 \\
\hline Above $150[\mathrm{mg} / \mathrm{dl}](\%)$ & $31.0 \%$ & $41.7 \%$ & \multicolumn{2}{|c|}{$16.7 \%$} & 0.08 \\
\hline \multicolumn{6}{|l|}{ Medical history } \\
\hline Hypertension duration [months] & $12.6 \pm 11.2$ & $14.4 \pm 12.0$ & \multicolumn{2}{|c|}{$10.3 \pm 9.8$} & 0.24 \\
\hline Smokers (\%) & $59.5 \%$ & $62.5 \%$ & \multicolumn{2}{|c|}{$55.6 \%$} & 0.65 \\
\hline Family history of hypertension (\%) & $71.4 \%$ & $79.2 \%$ & \multicolumn{2}{|c|}{$61.1 \%$} & 0.20 \\
\hline Primary education (\%) & $14.3 \%$ & $12.5 \%$ & \multicolumn{2}{|c|}{$16.7 \%$} & 0.70 \\
\hline Secondary education $(\%)$ & $52.4 \%$ & $62.5 \%$ & \multicolumn{2}{|c|}{$38.9 \%$} & 0.13 \\
\hline Higher education (\%) & $33.3 \%$ & $25.0 \%$ & \multicolumn{2}{|c|}{$44.4 \%$} & 0.19 \\
\hline \multicolumn{6}{|l|}{ Neurocognitive tests: } \\
\hline CDT [scores] & $7.9 \pm 2.0$ & $8.0 \pm 2.0$ & \multicolumn{2}{|c|}{$7.9 \pm 2.1$} & 0.85 \\
\hline MMSE [scores] & $27.6 \pm 1.8$ & $27.8 \pm 1.6$ & \multicolumn{2}{|c|}{$27.4 \pm 2.1$} & 0.44 \\
\hline MoCA [scores] & $24.9 \pm 2.5$ & $25.5 \pm 2.2$ & \multicolumn{2}{|c|}{$24.2 \pm 2.7$} & 0.08 \\
\hline
\end{tabular}

CDT — Clock Drawing Test; MMSE — Mini-Mental State Examination; MoCA — Montreal Assessment Cognitive Scale

understood yet. An impact of midlife hypertension on the development of cognitive impairment has been recently extensively studied and there is growing evidence that elevated blood pressure is the most powerful among modifiable risk factors for cerebral vessel dysfunction that contribute to cognitive decline in later life [15, 31-36]. Numerous studies addressed this issue to specific blood pressure cut-offs, or more recently - exclusively to systolic blood pressure values $[13,14,16,31]$. In this pilot study, we investigated a potential role of short-term blood pressure variations in cognitive impairments.

In clinical practice, $A B P M$ is a method that allows not only to evaluate the effectiveness of antihypertensive therapy but also highly useful in predicting cardiovascular risk in patients with hypertension [37-41]. ABPM provides valuable information on the circadian variability of blood pressure and blood pressure patterns, which have been shown to be predictive for cognitive function [21, 42, 43]. Clinical studies in humans have demonstrated the strong association of cognitive impairment and VD with non-dipping, reverse-dipping and, extreme-dipping blood pressure patterns diagnosed by conventional 24-hour ABPM [22-25].

In our study, we found the presence of a non-dipping pattern in over $60 \%$ of patients. However, we did not find any differences in the neuropsychological test scores between the groups with normal and non-dipping pattern. A vast majority of studies 
reporting such relationship suggested a potential role of secondary, hypertension-related the cerebral white matter lesions, higher frequency of lacunar infarction and reduction of total brain matter, which were strongly influenced by age [44-46]. In contrast to these reports, our study population was relatively younger and had no history of the symptomatic cerebrovascular disease. Furthermore, in contrast to the blood flow in other organs, cerebral blood flow increases during the night as a result of an increased oxygen demand [47]. Some authors suggest that in

Table II. Blood pressure values and circadian variability (24 hour ABPM)

\begin{tabular}{|c|c|}
\hline Blood pressure & Mean ( \pm SD) \\
\hline 24SBP [mm Hg] & $125.6 \pm 13.5$ \\
\hline $24 \mathrm{DBP}[\mathrm{mm} \mathrm{Hg}]$ & $75.9 \pm 9.8$ \\
\hline 24MAP [mm Hg] & $92.9 \pm 9.8$ \\
\hline SBPd [mm Hg] & $128.1 \pm 14.2$ \\
\hline $\mathrm{DBPd}[\mathrm{mm} \mathrm{Hg}]$ & $78.3 \pm 10.2$ \\
\hline MAPd [mm Hg] & $95.1 \pm 10.3$ \\
\hline SBPn [mm Hg] & $118.1 \pm 13.6$ \\
\hline DBPn [mm Hg] & $69.9 \pm 8.8$ \\
\hline MAPn [mm Hg] & $87.1 \pm 8.9$ \\
\hline CV [\%] & $12.2 \pm 3.1$ \\
\hline 24MAP SD [mm Hg] & $11.4 \pm 3.2$ \\
\hline $\mathrm{PP}[\mathrm{mm} \mathrm{Hg}]$ & $49.7 \pm 9.1$ \\
\hline Dippers (\%) & $36.6 \%$ \\
\hline Non-dippers (\%) & $61.0 \%$ \\
\hline Reverse-dippers (\%) & $2.4 \%$ \\
\hline
\end{tabular}

24SBP — 24-hour Systolic Blood Pressure; 24DBP — 24-hour Diastolic Blood Pressure; 24MAP_24-hour Mean Blood Pressure; SBPd — Daytime Systolic Blood pressure; DBPd — Daytime Diastolic Blood Pressure; MAPd - Daytime Mean Blood Pressure; SBPn — Nocturnal Systolic Blood Pressure; DBPn — Nocturnal Diastolic Blood Pressure; MAPn — Nocturnal Mean Blood Pressure; CV - Coefficient of Variation; 24 MAP SD - 24-hour Mean Blood Pressure Variability Estimated by Standard Deviation; PP — pulse pressure hypertensive patients a blunted reduction in nocturnal blood pressure may play an adaptive role in maintaining the night-time cerebral blood flow when autoregulatory mechanisms fail [48]. However, it seems unclear whether this adaptive mechanism is essential also in middle-aged patients without prior cerebrovascular events.

It has been well documented that aside from the conventional 24-h ABPM analysis, the ABPM indicators of short-term BPV may possess prognostic potential in the assessment of cerebrovascular risk $[22,26,27,49]$. We found the scores in neuropsychological tests were inversely correlated with 24-h SD and CV. Bellelli et al. [49] demonstrated the association between cognitive decline and increased 24-hour BPV-CV in the elderly. They suggested that in hypertensive patients with the cognitive decline the sympathetic nervous system affects short-term BPV and its activation may be related to impaired baroreceptor response. Further studies are

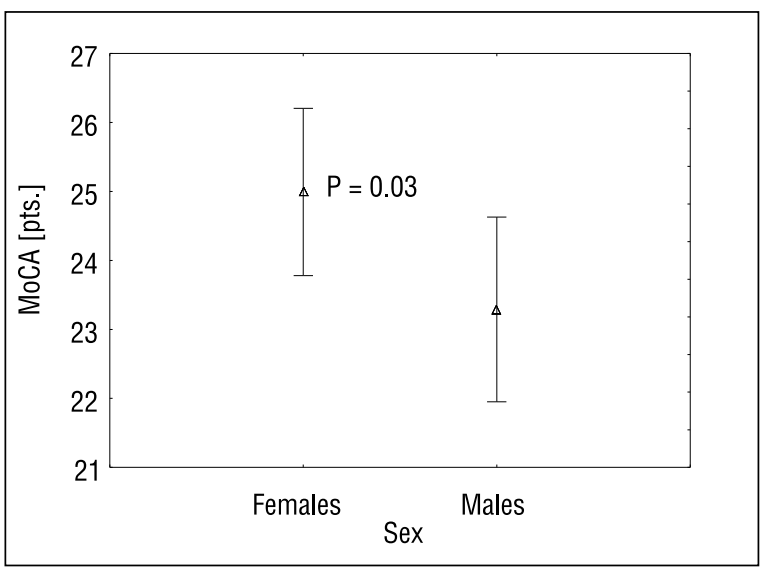

Figure 1. MoCA scores by gender adjusted for age — education level and lipid profiles

Table III. The relationship between blood pressure variability and pulse pressure with neuropsychological test scores

\begin{tabular}{|l|c|c|c|}
\hline ABPM variable & Cognitive test & R & P-value \\
\hline \multirow{3}{*}{ CV [\%] } & CDT & -0.37 & 0.03 \\
\cline { 2 - 4 } & MMSE & -0.13 & 0.44 \\
\cline { 2 - 4 } & MoCA & -0.36 & 0.02 \\
\hline \multirow{3}{*}{24 MAP SD $[\mathrm{mm} \mathrm{Hg}]$} & CDT & -0.40 & 0.02 \\
\cline { 2 - 4 } & MMSE & -0.08 & 0.64 \\
\cline { 2 - 4 } & MoCA & -0.27 & 0.09 \\
\hline \multirow{3}{*}{$\operatorname{PP}[\mathrm{mm} \mathrm{Hg}]$} & CDT & 0.02 & 0.91 \\
\cline { 2 - 4 } & MMSE & 0.06 & 0.73 \\
\cline { 2 - 4 } & MoCA & 0.13 & 0.41 \\
\hline
\end{tabular}

CV — The Coefficient of Variation; 24MAP SD — 24-hour Mean Blood Pressure Variability (SD); PP — Pulse Pressure; CDT — Clock Drawing Test; MMSE — Mini-Mental State Examination; MoCA — Montreal Assessment Cognitive Scale; R — Spearman's Rank Correlation Coefficient 
needed to elucidate whether this mechanism is also relevant in younger patients with uncomplicated hypertension.

We found significantly lower scores in the MoCA test in males in comparison to females. In the general population, cognitive decline is more common in women than in men. This is explained mostly by the longer life span [50-53] as well as an impact of genetics factors, sex hormone changes in midlife, and lower cognitive reserve that results in faster cognitive decline in women $[50,54,55]$. On the other hand, other studies demonstrated that compared with females, males showed significantly worse performance in Assessment Scale-cognitive subscale 13 (ADAS) evaluating subjective cognitive decline [56]. These gender discrepancies may be related to differences in cognitive domains evaluated by various neuropsychological tests. In this study, we used the MoCA scale, which is more specific for the assessment of memory, executive functions and psychomotor performance [57]. The MoCA scores are typically worse in the vascular cognitive decline associated with hypertension [58-60]. Our results seem consistent with earlier studies reporting that males have faster memory decline due to the typically earlier onset of cardiovascular disease, including primary hypertension $[50,61,62]$.

\section{Conclusions}

In this a pilot-based study, mild cognitive impairment in middle-aged patients with long-lasting uncomplicated hypertension may be associated with increased diurnal variability of blood pressure.

\section{Conflict of interest statement}

The authors declare no conflict of interests.

\section{References}

1. Mamcarz A, Mastalerz-Migas A, Mirowska-Guzel D, et al. Stanowisko interdyscyplinarnego zespołu ekspertów dotyczące leczenia pacjentów z nadciśnieniem tętniczym łistniejącymi zaburzeniami funkcji poznawczych w codziennej praktyce lekarskiej. Arterial Hypertens. 2017; 4: 153-166.

2. Ivan CS, Seshadri S, Beiser A, et al. Dementia after stroke: the Framingham Study. Stroke. 2004; 35(6): 1264-1268, doi: 10.1161/01. STR.0000127810.92616.78, indexed in Pubmed: 15118167.

3. O'Brien JT, Erkinjuntti T, Reisberg B, et al. Vascular cognitive impairment. Lancet Neurol. 2003; 2(2): 89-98, indexed in Pubmed: 12849265.

4. Poggesi A, Pantoni L, Inzitari D, et al. LADIS Study Group, The LADIS Study Group. 2001-2011: A Decade of the LADIS (Leukoaraiosis And DISability) Study: What Have We Learned about White Matter Changes and Small-Vessel Disease? Cerebrovasc Dis. 2011; 32(6): 577-588, doi: 10.1159/000334498, indexed in Pubmed: 22277351.
5. Pantoni L. Cerebral small vessel disease: from pathogenesis and clinical characteristics to therapeutic challenges. The Lancet Neurology. 2010; 977): 689-701, doi: 10.1016/s1474-4422(10)70104-6.

6. Sierra C, de la Sierra A, Chamorro A, et al. Silent cerebral white matter lesions in middle-aged essential hypertensive patients. J Hypertens. 2002; 20(3): 519-524, indexed in Pubmed: 11875320.

7. Wong TY, Klein R, Sharrett AR, et al. Retinal microvascular abnormalities and cognitive impairment in middle-aged persons: the Atherosclerosis Risk in Communities Study. Stroke. 2002; 33(6): 1487-1492, indexed in Pubmed: 12052979.

8. Inaba S, Iwai M, Furuno M, et al. Continuous activation of renin-angiotensin system impairs cognitive function in renin/angiotensinogen transgenic mice. Hypertension. 2009; 53(2): 356-362, doi: 10.1161/HYPERTENSIONAHA.108.123612, indexed in Pubmed: 19047580.

9. Głuszek J, Jankowska K. Zmiany otępienne wywołane nadciśnieniem tętniczym. Choroby Serca Naczyń. 2005; 3: 125-130.

10. Birns J, Morris R, Donaldson N, et al. The effects of blood pressure reduction on cognitive function: a review of effects based on pooled data from clinical trials. J Hypertens. 2006; 24(10): 1907-1914, doi: 10.1097/01.hjh.0000244934.81180.16, indexed in Pubmed: 16957545.

11. Elias PK, Elias MF, Robbins MA, et al. Blood pressure-related cognitive decline: does age make a difference? Hypertension. 2004; 44(5): 631-636, doi: 10.1161/01.HYP.0000145858.07252.99, indexed in Pubmed: 15466661.

12. Richard E, Reitz C, Honig LH, et al. Relation of diabetes to mild cognitive impairment. Arch Neurol. 2007; 64(4): 570-575, doi: 10.1001/archneur.64.4.570, indexed in Pubmed: 17420320.

13. Shang S, Li P, Deng M, et al. The Age-Dependent Relationship between Blood Pressure and Cognitive Impairment: A Cross-Sectional Study in a Rural Area of Xi'an, China. PLoS One. 2016; 11(7): e0159485, doi: 10.1371/journal.pone.0159485, indexed in Pubmed: 27438476.

14. Zou Y, Zhu Q, Deng Y, et al. Vascular risk factors and mild cognitive impairment in the elderly population in Southwest China. Am J Alzheimers Dis Other Demen. 2014; 29(3): 242-247, doi: 10.1177/1533317513517042, indexed in Pubmed: 24375574.

15. Gelber RP, Ross GW, Petrovitch H, et al. The association between midlife blood pressure levels and late-life cognitive function. The Honolulu-Asia Aging Study. JAMA. 1995; 274(23): 1846-1851, indexed in Pubmed: 7500533.

16. Li Ge, Rhew IC, Shofer JB, et al. Age-varying association between blood pressure and risk of dementia in those aged 65 and older: a community-based prospective cohort study. J Am Geriatr Soc. 2007; 55(8): 1161-1167, doi: 10.1111/j.1532-5415.2007.01233.x, indexed in Pubmed: 17661953.

17. Cacciatore F, Abete P, Ferrara N, et al. The role of blood pressure in cognitive impairment in an elderly population. Osservatorio Geriatrico Campano Group. J Hypertens. 1997; 15(2): 135-142, indexed in Pubmed: 9469788.

18. Kilander L, Nyman H, Boberg M, et al. Hypertension is related to cognitive impairment: a 20-year follow-up of 999 men. Hypertension. 1998; 31(3): 780-786, indexed in Pubmed: 9495261.

19. Razay G, Williams J, King E, et al. Blood pressure, dementia and Alzheimer's disease: the OPTIMA longitudinal study. Dement Geriatr Cogn Disord. 2009; 28(1): 70-74, doi: 10.1159/000230877, indexed in Pubmed: 19648748.

20. Skoog I, Lernfelt B, Landahl S, et al. 15-year longitudinal study of blood pressure and dementia. Lancet. 1996; 347(9009): 1141-1145, indexed in Pubmed: 8609748.

21. Dore GA, Elias MF, Crichton GE, et al. Age modifies the relation between intraindividual measurement-to-measurement variation in blood pressure and cognitive function: the Maine-Syracuse Study. J Hypertens. 2018; 36(2): 268-276, doi: $10.1097 / \mathrm{HJH} .0000000000001510$, indexed in Pubmed: 28787305.

22. Mergeani AC, Antochi F, Rusu O, et al. Correlations of Cognitive Impairment with Circadian Blood Pressure Pattern and Intima-Media Thickness in Hypertensive Patients. Maedica (Buchar). 2015; 10(4): 325-330, indexed in Pubmed: 28465733. 
23. van Boxtel MP, Gaillard C, Houx PJ, et al. Is nondipping in $24 \mathrm{~h}$ ambulatory blood pressure related to cognitive dysfunction? J Hypertens. 1998; 16(10): 1425-1432, indexed in Pubmed: 9814612.

24. Guo $\mathrm{H}$, Tabara $Y$, Igase $\mathrm{M}$, et al. Abnormal nocturnal blood pressure profile is associated with mild cognitive impairment in the elderly: the J-SHIPP study. Hypertens Res. 2010; 33(1): 32-36, doi: 10.1038/ hr.2009.172, indexed in Pubmed: 19851324.

25. Komori T, Eguchi K, Saito T, et al. Riser Blood Pressure Pattern Is Associated With Mild Cognitive Impairment in Heart Failure Patients. Am J Hypertens. 2016; 29(2): 194-201, doi: 10.1093/ ajh/hpv086, indexed in Pubmed: 26066331.

26. Angeli F, Reboldi G, Verdecchia P. Interpretation of ambulatory blood pressure profile: a prognostic approach for clinical practice. J Hypertens. 2015; 33(3): 454-457, doi: $10.1097 /$ HJH.0000000000000497, indexed in Pubmed: 25629359.

27. Yaneva-Sirakova T, Tarnovska-Kadreva R, Traykov L. Pulse pressure and mild cognitive impairment. J Cardiovasc Med (Hagerstown). 2012; 13(11): 735-740, doi: 10.2459/JCM.0b013e328357ba78, indexed in Pubmed: 22929565.

28. Yasar S, Ko JY, Nothelle S, et al. Evaluation of the effect of systolic blood pressure and pulse pressure on cognitive function: the Women's Health and Aging Study II. PLoS One. 2011; 6(12): e27976, doi: 10.1371/journal.pone.0027976, indexed in Pubmed: 22174760.

29. Riba-Llena I, Nafría C, Filomena J, et al. High daytime and nighttime ambulatory pulse pressure predict poor cognitive function and mild cognitive impairment in hypertensive individuals. J Cereb Blood Flow Metab. 2016; 36(1): 253-263, doi: 10.1038/jcbfm.2015.90, indexed in Pubmed: 25966945.

30. Tykarski A, Narkiewicz K, Gaciong Z, et al. Guidelines for the Management of Hypertension. Arterial Hypertension. 2015; 19(2): 53-83, doi: 10.5603/ah.2015.0010.

31. Gąsecki D, Kwarciany M, Nyka W, et al. Hypertension, brain damage and cognitive decline. Curr Hypertens Rep. 2013; 15(6): 547-558, doi: 10.1007/s1 1906-013-0398-4, indexed in Pubmed: 24146223.

32. Elias MF, Wolf PA, D'Agostino RB, et al. Untreated blood pressure level is inversely related to cognitive functioning: the Framingham Study. Am J Epidemiol. 1993; 138(6): 353-364, indexed in Pubmed: 8213741.

33. Whitmer RA, Sidney S, Selby J, et al. Midlife cardiovascular risk factors and risk of dementia in late life. Neurology. 2005; 64(2): 277-281, doi: 10.1212/01.WNL.0000149519.47454.F2, indexed in Pubmed: 15668425.

34. Qiu C, Winblad B, Fratiglioni L. The age-dependent relation of blood pressure to cognitive function and dementia. Lancet Neurol. 2005; 4(8): 487-499, doi: 10.1016/S1474-4422(05)70141-1, indexed in Pubmed: 16033691.

35. Gelber RP, Ross GW, Petrovitch H, et al. Midlife blood pressure and dementia: the Honolulu-Asia aging study. Neurobiol Aging. 2000; 21(1): 49-55, indexed in Pubmed: 10794848.

36. Yamada M, Shimizu M, Kasagi F, et al. Association between dementia and midlife risk factors: the Radiation Effects Research Foundation Adult Health Study. J Am Geriatr Soc. 2003; 51(3): 410-414, indexed in Pubmed: 12588587.

37. Mancia G, Fagard R, Narkiewicz K, et al. Task Force for the Management of Arterial Hypertension of the European Society of Hypertension and the European Society of Cardiology, ESH/ ESC Task Force for the Management of Arterial Hypertension, Task Force Members, Task Force for the management of arterial hypertension of the European Society of Hypertension, Task Force for the management of arterial hypertension of the European Society of Cardiology. 2013 ESH/ESC guidelines for the management of arterial hypertension: the Task Force for the Management of Arterial Hypertension of the European Society of Hypertension (ESH) and of the European Society of Cardiology (ESC). Eur Heart J. 2013; 34(28): 2159-2219, doi: 10.1093/eurheartj/eht151, indexed in Pubmed: 23771844.

38. Tykarski A, Narkiewicz K, Gaciong Z, et al. Zasady postępowania w nadciśnieniu tętniczym - 2015 rok. Wytyczne Polskiego Towarzystwa Nadciśnienia Tętniczego — wersja skrócona. Kardiologia Polska. 2015; 73(8): 676-700, doi: 10.5603/kp.2015.0157.
39. Angeli F, Reboldi G, Verdecchia P. Interpretation of ambulatory blood pressure profile: a prognostic approach for clinical practice. J Hypertens. 2015; 33(3): 454-457, doi: $10.1097 /$ HJH.0000000000000497, indexed in Pubmed: 25629359.

40. Verdecchia P, Angeli F. Natural history of hypertension subtypes. Circulation. 2005; 111(9): 1094-1096, doi: 10.1161/01. CIR.0000158690.78503.5F, indexed in Pubmed: 15753224.

41. Verdecchia P, Angeli F. [The Seventh Report of the Joint National Committee on the Prevention, Detection, Evaluation and Treatment of High Blood Pressure: the weapons are ready]. Rev Esp Cardiol. 2003; 56(9): 843-847, indexed in Pubmed: 14519269.

42. Waldstein SR, Katzel LI. Hypertension and cognitive function. In: Waldstein SR, Elias MF, eds. Neuropsychology of Cardiovascular Disease.Mahawah NJ. ed. Mahwah, NJ: Lawrence Erlbaum Associates : $15-36$.

43. Elias MF, Robbins MA, Schultz NR, et al. Is blood pressure an important variable in research on aging and neuropsychological test performance? J Gerontol. 1990; 45(4): P128-P135, indexed in Pubmed: 2195104.

44. Nagai M, Hoshide S, Ishikawa J, et al. Ambulatory blood pressure as an independent determinant of brain atrophy and cognitive function in elderly hypertension. J Hypertens. 2008; 26(8): 1636-1641, doi: 10.1097/HJH.0b013e3283018333, indexed in Pubmed: 18622243.

45. Sander D, Winbeck K, Klingelhöfer J, et al. Extent of cerebral white matter lesions is related to changes of circadian blood pressure rhythmicity. Arch Neurol. 2000; 57(9): 1302-1307, indexed in Pubmed: 10987897.

46. Kario K, Matsuo T, Kobayashi H, et al. Nocturnal fall of blood pressure and silent cerebrovascular damage in elderly hypertensive patients. Advanced silent cerebrovascular damage in extreme dippers. Hypertension. 1996; 27(1): 130-135, indexed in Pubmed: 8591875.

47. Townsend RE, Prinz PN, Obrist WD. Human cerebral blood flow during sleep and waking. J Appl Physiol. 1973; 35(5): 620-625, doi: 10.1152/jappl.1973.35.5.620, indexed in Pubmed: 4358783.

48. Metoki H, Ohkubo T, Kikuya M, et al. Influence of age on the nocturnal fall of blood pressure and its modulation by long-acting calcium antagonists. Clin Exp Hypertens A. 1990; 12(6): 1077-1094, indexed in Pubmed: 2245516.

49. Bellelli G, Pezzini A, Bianchetti A, et al. Increased blood pressure variability may be associated with cognitive decline in hypertensive elderly subjects with no dementia. Arch Intern Med. 2002; 162(4): 483-484, indexed in Pubmed: 11863487.

50. Sohn D, Shpanskaya K, Lucas JE, et al. Sex Differences in Cognitive Decline in Subjects with High Likelihood of Mild Cognitive Impairment due to Alzheimer's disease. Sci Rep. 2018; 8(1): 7490, doi: 10.1038/s41598-018-25377-w, indexed in Pubmed: 29748598.

51. Lin KA, Choudhury KR, Rathakrishnan BG, et al. Alzheimer's Disease Neuroimaging Initiative. Marked gender differences in progression of mild cognitive impairment over 8 years. Alzheimers Dement (N Y). 2015; 1(2): 103-110, doi: 10.1016/j.trci.2015.07.001, indexed in Pubmed: 26451386.

52. Barnes LL, Wilson RS, Bienias JL, et al. Sex differences in the clinical manifestations of Alzheimer disease pathology. Arch Gen Psychiatry. 2005; 62(6): 685-691, doi: 10.1001/archpsyc.62.6.685, indexed in Pubmed: 15939846.

53. Irvine K, Laws KR, Gale TM, et al. Greater cognitive deterioration in women than men with Alzheimer's disease: a meta analysis. J Clin Exp Neuropsychol. 2012; 34(9): 989-998, doi: 10.1080/13803395.2012.712676, indexed in Pubmed: 22913619.

54. Mielke MM, Vemuri P, Rocca WA. Clinical epidemiology of Alzheimer's disease: assessing sex and gender differences. Clin Epidemiol. 2014; 6: 37-48, doi: 10.2147/CLEP.S37929, indexed in Pubmed: 24470773.

55. Henderson VW, Paganini-Hill A, Miller BL, et al. Estrogen deficiency and risk of Alzheimer's disease in women. Am J Epidemiol. 1994; 140(3): 256-261, indexed in Pubmed: 8030628.

56. Wang L, Tian T. Alzheimer's Disease Neuroimaging Initiative. Gender Differences in Elderly With Subjective Cognitive Decline. Front Aging Neurosci. 2018; 10: 166, doi: 10.3389/fnagi.2018.00166, indexed in Pubmed: 29915534. 
57. Nasreddine ZS, Phillips NA, Bédirian V, et al. The Montreal Cognitive Assessment, MoCA: a brief screening tool for mild cognitive impairment. J Am Geriatr Soc. 2005; 53(4): 695-699, doi: 10.1111/j.1532-5415.2005.53221.x, indexed in Pubmed: 15817019

58. Popović IM, Serić V, Demarin V. Mild cognitive impairment in symptomatic and asymptomatic cerebrovascular disease. J Neurol Sci. 2007; 257(1-2): 185-193, doi: 10.1016/j.jns.2007.01.029, indexed in Pubmed: 17328916.

59. Wong A, Xiong YY, Kwan PWL, et al. The validity, reliability and clinical utility of the Hong Kong Montreal Cognitive Assessment (HK-MoCA) in patients with cerebral small vessel disease. Dement Geriatr Cogn Disord. 2009; 28(1): 81-87, doi: 10.1159/000232589, indexed in Pubmed: 19672065.
60. Dong Y, Sharma VK, Chan BPL, et al. The Montreal Cognitive Assessment (MoCA) is superior to the Mini-Mental State Examination (MMSE) for the detection of vascular cognitive impairment after acute stroke. J Neurol Sci. 2010; 299(1-2): 15-18, doi: 10.1016/j. jns.2010.08.051, indexed in Pubmed: 20889166.

61. Maylor EA, Reimers S, Choi J, et al. Gender and sexual orientation differences in cognition across adulthood: age is kinder to women than to men regardless of sexual orientation. Arch Sex Behav. 2007; 36(2): 235-249, doi: 10.1007/s10508-006-9155-y, indexed in Pubmed: 17351741

62. Roberts RO, Geda YE, Knopman DS, et al. The incidence of MCI differs by subtype and is higher in men: the Mayo Clinic Study of Aging. Neurology. 2012; 78(5): 342-351, doi: 10.1212/ WNL.0b013e3182452862, indexed in Pubmed: 22282647. 